\title{
Article \\ Degradation of Azo Dyes with Different Functional Groups in Simulated Wastewater by Electrocoagulation
}

\author{
Yang Liu ${ }^{1, *}$, Chenglong Li ${ }^{1}$, Jia Bao ${ }^{1, *}$, Xin Wang ${ }^{1}$, Wenjing Yu ${ }^{2}$ and Lixin Shao ${ }^{1}$ \\ 1 School of Environmental and Chemical Engineering, Shenyang University of Technology, \\ Shenyang 110870, China; lichenglong@sut.edu.cn (C.L.); xinwang@sut.edu.cn (X.W.); \\ shaolx@sut.edu.cn (L.S.) \\ 2 School of Water Resources \& Environment, China University of Geosciences, Beijing 100083, China; \\ yuwenjing@sut.edu.cn \\ * Correspondence: liuyang@sut.edu.cn (Y.L.); baojia@sut.edu.cn (J.B.)
}

Citation: Liu, Y.; Li, C.; Bao, J.; Wang, X.; Yu, W.; Shao, L. Degradation of Azo Dyes with Different Functional Groups in Simulated Wastewater by Electrocoagulation. Water 2022, 14, 123. https://doi.org/10.3390/ w14010123

Academic Editor: Alexandre

T. Paulino

Received: 20 October 2021

Accepted: 3 January 2022

Published: 5 January 2022

Publisher's Note: MDPI stays neutral with regard to jurisdictional claims in published maps and institutional affiliations.

Copyright: (C) 2022 by the authors. Licensee MDPI, Basel, Switzerland. This article is an open access article distributed under the terms and conditions of the Creative Commons Attribution (CC BY) license (https:// creativecommons.org/licenses/by/ $4.0 /)$.

\begin{abstract}
Increasing attention has been paid to the widespread contamination of azo dyes in water bodies globally. These chemicals can present high toxicity, possibly causing severe irritation of the respiratory tract and even carcinogenic effects. The present study focuses on the periodically reverse electrocoagulation (PREC) treatment of two typical azo dyes with different functional groups, involving methyl orange (MO) and alizarin yellow (AY), using Fe-Fe electrodes. Based upon the comparative analysis of three main parameters, including current intensity, $\mathrm{pH}$, and electrolyte, the optimal color removal rates for MO and AY could be achieved at a rate of up to $98.7 \%$ and $98.6 \%$, respectively, when the current intensity is set to $0.6 \mathrm{~A}$, the $\mathrm{pH}$ is set at 6.0 , and the electrolyte is selected as $\mathrm{NaCl}$. An accurate predicted method of response surface methodology (RSM) was established to optimize the PREC process involving the three parameters above. The reaction time was the main influence for both azo dyes, while the condition of PREC treatment for AY simulated wastewater was time-saving and energy conserving. According to the further UV-Vis spectrophotometry analysis throughout the procedure of the PREC process, the removal efficiency for AY was better than that of $\mathrm{MO}$, potentially because hydroxyl groups might donate electrons to iron flocs or electrolyze out hydroxyl free radicals. The present study revealed that the functional groups might pose a vital influence on the removal efficiencies of the PREC treatment for those two azo dyes.
\end{abstract}

Keywords: azo dyes; functional groups; chemical oxygen demand (COD); color removal; response surface methodology (RSM); periodically reverse electrocoagulation (PREC)

\section{Introduction}

The environmental problems originating from the textile industry have been receiving increasing attentions for several decades, since the textile industry is one of the major sources of contaminated effluents [1]. Azo dyes are the most widely used dyes and comprise over $60 \%$ of the total dyes used [2]; these dyes include compounds consisting of a diazotized amine coupled to an amine or a phenol, as well as containing one or more azo linkages. According to the statistical data reported previously, azo dyes account for over $80 \%$ of the total dyes produced globally each year, and they have been widely used in the textile and dyeing, papermaking, printing, leather, cosmetics and pharmaceutical industries [3]. Presumably, around 2000 types of azo dyes are currently used, and more than 70,000 tons of these dyes are manufactured worldwide annually [4]. For example, the textile water consumption values in the tops/fiber and yarn production vary between 35 and $180 \mathrm{~L}_{\text {per }} \mathrm{kg}^{-1}$ of product. Moreover, the water consumption values in the yarn mills range between 43 and $212 \mathrm{~L} \mathrm{per} \mathrm{kg}^{-1}$ of product, and those in the fabric finishing mills were in the range of 60 and $216 \mathrm{~L} \mathrm{per} \mathrm{kg}^{-1}$ of product [5].

Azo dyes can have negative impacts on the water quality of both surface water and groundwater, such as blocking light transmission, affecting photosynthesis of plants and 
algae in water, and reducing dissolved oxygen in water [6]. Furthermore, azo dyes could be accumulated in the aquatic systems, possibly causing carcinogenicity and mutagenicity to various species of fishes $[7,8]$. Azo dyes can transport along both aquatic and terrestrial pathways, thus entering the food chain and then posing health risks to organisms and humans [9]. Moreover, azo dye wastewaters have several adverse impacts on the aquatic environment in terms of the total organic carbon (TOC), biochemical oxygen demand (BOD), chemical oxygen demand (COD), suspended solids (SS), salinity, color, and a wide range of $\mathrm{pH}(5-12)$. Normally, the ratio of BOD/COD for azo dye wastewaters ranges from 0.2 to 0.5 , indicating that these effluents contain a large proportion of non-biodegradable organic matter [2]. The presence of azo dyes in surface and subsurface water might make the aquatic organisms intolerable, and may even lead to many diseases of mucous membranes in the human body, e.g., dermatitis, perforation of the nasal septum, and severe irritation of the respiratory tract [10]. Therefore, the treatment of azo dye wastewaters has become an important environmental concern [11].

Azo dyes are characterized by the variety in chemical structures, resulting in environmental stability against heat and ultraviolet light and resistance to microbial degradation or discoloration. For instance, azo dyes usually contain a strong stable benzene ring structure, and even dissolved functional groups of sulfonate, hydroxyl, or carboxyl, leading to difficulty in carrying out water treatment. Some modern technologies have been applied to mitigate the degradation of azo dyes, such as electrochemical methods, ozone oxidation, photo Fenton, chemical precipitation, membrane separation, adsorption, and photocatalysis [12-14]. However, the material regeneration performance of adsorption technology would be inefficient, and membrane separation technology might be restricted by membrane pollution and unstable membrane flux, while other technologies require strict operating conditions, such as high material cost, long processing time, or high energy consumption $[15,16]$. Recent studies have demonstrated that electrochemical methods have been widely employed in the degradation of organic pollutants in various wastewaters, because of high removal efficiency and low energy consumption [17]. Electrochemical methods comprise electrocoagulation (EC), electrocatalytic oxidation [18], bioelectrochemistry [19], and electroreduction [20]. Among them, the EC method has the advantage of strong applicability, a high degree of automation, high efficiency, and low cost, and thus could be an attractive treatment technique for dye wastewaters.

The EC process involves the dissolution of charged cations (e.g., $\mathrm{Zn}^{2+}, \mathrm{Al}^{3+}, \mathrm{Fe}^{3+}$ ) originated from the sacrificial anode, forming monomeric and polymeric hydroxyl complex species simultaneously, which can strongly sorb certain pollutants from contaminated water [21]. For instance, $95.3 \%$ of brilliant green dye and $98 \%$ of reactive red 120 dye from drinking water could be removed by the EC process $[22,23]$. Nunez et al. used the EC technique for the dye degradation in wastewater in a batch-stirred EC reactor with iron and aluminum as anode materials simultaneously, and subsequently the removal efficiency of color and COD achieved was $86 \%$ and $59 \%$, respectively [24].

Compared with the conventional EC technique, the periodically reverse electrocoagulation (PREC) technique could remove unmanageable perfluoroalkyl substances (PFASs) swiftly and efficiently, and avoid passivation on the electrode surface in the practical applications [25-27]. So far, researchers have always focused on the EC efficiency for azo dyes, however, different functional groups of azo dyes results in EC treatment having various degrees of efficiency. For instance, the optimum color removal efficiency of indigo carmine (IC) was $72 \%$ by the EC technique [28], while the color removal rate of reactive red 120 was $93.47 \%$ [29]. Therefore, further studies would be warranted to focus on the operating conditions, removal efficiencies, and degradation mechanisms of the PREC technique for the treatment of typical azo dyes with different functional groups in various wastewaters.

In the present study, the PREC technique was applied to achieve the following objectives: (1) comparing the treatment efficiency of PREC for the simulated aqueous solution containing either methyl orange (MO) or alizarin yellow (AY) with single-factor involving current intensity, $\mathrm{pH}$, and electrolyte; (2) establishing a reliable model of response surface 
methodology (RSM) to investigate the main effects of multiple factors and determine the optimal PREC process to remove azo dyes; and (3) reveal the degradation mechanism via further spectrophotometry analysis on diverse functional groups of $\mathrm{MO}$ and AY.

\section{Materials and Methods}

\subsection{Chemicals and Reagents}

Methyl orange (99.9\%) and alizarin yellow (99.9\%) were acquired from Fluka (Steinheim, Germany). HPLC grade of sodium chloride $(\mathrm{NaCl})$, hydrochloric acid $(\mathrm{HCl})$, sodium carbonate $\left(\mathrm{Na}_{2} \mathrm{CO}_{3}\right)$, sodium sulfate $\left(\mathrm{Na}_{2} \mathrm{SO}_{4}\right)$, and ethanol $\left(\mathrm{C}_{2} \mathrm{H}_{6} \mathrm{O}\right)$ were purchased from Acros Organics (Geel, Belgium). All solutions were prepared using ultrapure water with a conductance of $18.2 \mathrm{M} \Omega \mathrm{cm}^{-1}$ (Millipore, Bedford, MA, USA).

\subsection{Experimental Setup and Procedure}

The reactor for degradation of $\mathrm{MO}$ and $\mathrm{AY}$ in simulated wastewater was an organic glass electrolytic cell with an effective volume of $400 \mathrm{~mL}$ with two parallel metal electrodes, and the individual size of the electrode was $5 \mathrm{~cm} \times 4 \mathrm{~cm} \times 0.2 \mathrm{~cm}$. The electrodes were immersed vertically in simulated wastewater of MO or AY completely, and stirred continuously using a magnetic stirrer (IKARCT, Germany). The electrodes were connected to a digital DC power supply, characterized by the ranges of 0-3 A for current intensity and 0-30 V for voltage.

Mutual combinations by Fe-Fe electrodes were adopted for the PREC treatment of $\mathrm{MO}$ or AY wastewater, since iron is one of the most common elements in nature and fresh waters [30]. Contaminants could be oxidatively degraded, floated, enmeshed, or adsorbed by the metal hydroxide flocs generated in-situ by electro-oxidation, in turn as the sacrificial anode [26], while the passivation coating was eliminated as the cathode mode. In this study, iron was selected as the bipolar plate material. The plates were fully submerged into the solution in the reactor during all experiments, and were cleaned manually before each run by abrasion with sand paper and treatment with $15 \%$ hydrochloric acid, followed by washing with distilled water [27]. Based upon the important influence parameters mentioned earlier [31-33], the current intensity in the range between 0.4 and $0.8 \mathrm{~A}, \mathrm{pH}$ between 3.0 and 9.0, and three electrolytes of $\mathrm{Na}_{2} \mathrm{SO}_{4}, \mathrm{Na}_{2} \mathrm{CO}_{3}$, and $\mathrm{NaCl}$ with $2 \mathrm{~g} \mathrm{~L}^{-1}$ was selected for the optimal single-factor impact experimental design. In addition, the initial concentrations of both $\mathrm{MO}$ and $\mathrm{AY}$ in the simulated aqueous solution were set to $100 \mathrm{mg} \mathrm{L}^{-1}$, the gap between two electrodes was fixed at $2 \mathrm{~cm}$, stirring speed was $1000 \mathrm{r} \mathrm{min}^{-1}$, and the reversing time was $10 \mathrm{~s}$. An amount of $2 \mathrm{~mL}$ of simulated aqueous solution was sampled with an interval of $10 \mathrm{~min}$ and then filtered with $0.22 \mathrm{~mm}$ membrane (glass fiber filter) for the additional analysis of $\mathrm{MO}$ and $\mathrm{AY}$ concentration. Experiments were performed at the ambient temperature.

\subsection{Sample Preparation and Analysis}

The experiment duration of each PREC process was $50 \mathrm{~min}$. Samples were taken every ten minutes. The reactor effluent from $\mathrm{MO}$ and AY wastewater treatment was analyzed after filtration through a glass fiber membrane. The wavelength of the sample was scanned using an ultraviolet and visible (UV-Vis) spectrophotometer (DR 5000, Hach Company, Loveland, CO, USA) [34]. Subsequently, the absorbances were determined to calculate the color removal of $\mathrm{MO}$ and $\mathrm{AY}$ with the maximum absorption wavelengths of $462 \mathrm{~nm}$ and $372 \mathrm{~nm}$ and the standard curves for $\mathrm{MO}\left(\mathrm{y}=0.059 \mathrm{x}+0.0015, \mathrm{R}^{2}=0.996\right)$ and $\mathrm{AY}\left(\mathrm{y}=0.023 \mathrm{x}+0.0026, \mathrm{R}^{2}=0.999\right)$, respectively. After digestion of each sample, the COD was analyzed by the COD detector (ET 99718, Lovibond, Germany). An amount of 1.0 M of $\mathrm{H}_{2} \mathrm{SO}_{4}$ and $\mathrm{NaOH}$ individually were used to adjust the desired $\mathrm{pH}$ [34].

\subsection{Data Analysis}

1. Color Removal ( $) \%$ 


$$
\eta=\frac{A_{0}-A_{t}}{A_{0}} \%
$$

$\mathrm{A}_{0}$ and $\mathrm{A}_{\mathrm{t}}$ are the absorbances of $\mathrm{MO}$ and $\mathrm{AY}$ in wastewater at the corresponding wave length $(\lambda \max )$ before and after the treatment.

2. COD Removal $(\delta) \%$

$$
\delta=\frac{\left[(C O D)-\left(C O D_{t}\right)\right]}{C O D} \%
$$

$\mathrm{COD}$ and $\mathrm{COD}_{\mathrm{t}}$ are the chemical oxygen demand of $\mathrm{MO}$ and $\mathrm{AY}$ in wastewater before and after the treatment.

\subsection{RSM Experimental Design}

Design Expert V8.0.6.1 statistical software was used to carry out the experimental design, analysis of variance (ANOVA), mathematical modelling, and 3D response surface. Three important operating parameters involving the current intensity (A), time (min) and $\mathrm{pH}$ were studied and optimized using the Box-Benkhen Experimental Design (BBD) at three levels when the electrolyte was selected as $\mathrm{NaCl}$. The experimental factors and levels are shown in Table 1. The statistical significance of the produced models was evaluated through ANOVA. Residual plots and coefficients of determination $\left(\mathrm{R}^{2}\right.$, Adjusted $\mathrm{R}^{2}$, and Predicted $\mathrm{R}^{2}$ ) were presented to express the quality of the fitted models [31,32].

Table 1. Response surface test factor level table.

\begin{tabular}{cccc}
\hline \multirow{2}{*}{ Parameter } & \multicolumn{3}{c}{ Horizontal Extent } \\
\cline { 2 - 4 } & $-\mathbf{1}$ & $\mathbf{0}$ & $\mathbf{1}$ \\
\hline Current intensity (A) & 0.4 & 0.6 & 0.8 \\
Time (min) & 10 & 30 & 50 \\
$\mathrm{pH}$ & 3 & 6 & 9 \\
\hline
\end{tabular}

\section{Results and Discussion}

\subsection{The Influence of Current Intensity}

Current intensity is commonly considered as an important factor for removing pollutants effectively in the PREC process. The current intensity determines the amount of sacrifice electrodes dissolution, which affects the generation of metal hydroxide flocs, as well as the removal efficiency of contaminants consequently [35]. The influence of current intensity in the range between 0.4 and $0.8 \mathrm{~A}$ on $\mathrm{MO}$ or $\mathrm{AY}$ wastewater was investigated in this study, with the conditions of $2 \mathrm{~g} \mathrm{~L}^{-1} \mathrm{NaCl}$ and $\mathrm{pH}$ at 6.0. The color removal rates of $\mathrm{MO}$ and $\mathrm{AY}$ influenced by different current intensity are shown in Figure 1a. The color removal rates of $\mathrm{MO}$ and $\mathrm{AY}$ altogether increased with the current intensity, and the removal rates of $\mathrm{MO}$ and AY were up to $90.7 \%$ and $95.0 \%$ at $20 \mathrm{~min}$, respectively, when the current intensity was set at $0.6 \mathrm{~A}$. This verified that $\mathrm{MO}$ and $\mathrm{AY}$ tended to be removed by the adsorption of generation flocs [36]. Meanwhile, the higher removal rate of AY might result in more electron-donating groups involving - $\mathrm{OH}$ in $\mathrm{AY}$ that facilitate adsorption on flocs. According to the Faraday's law, the amount of sacrifice electrodes dissolution and $\mathrm{OH}^{-}$concentration were positively correlated with the current intensity, leading to additional hydroxide flocs formation that facilitate $\mathrm{MO}$ and $\mathrm{AY}$ adsorption. However, when the current intensity was set at $0.8 \mathrm{~A}$, an increase in the current intensity beyond the optimal value had little effect on the contaminant removal efficiency, as reported previously [37]. Because the extra current intensity would increase superfluous small size bubbles that resist aggregate formation for contamination adsorption [27]. In addition, extra current intensity would generate higher energy consumption and steady color removal. Therefore, the optimal current intensity for removing the colors of $\mathrm{MO}$ and $\mathrm{AY}$ in wastewater was determined as $0.6 \mathrm{~A}$. 

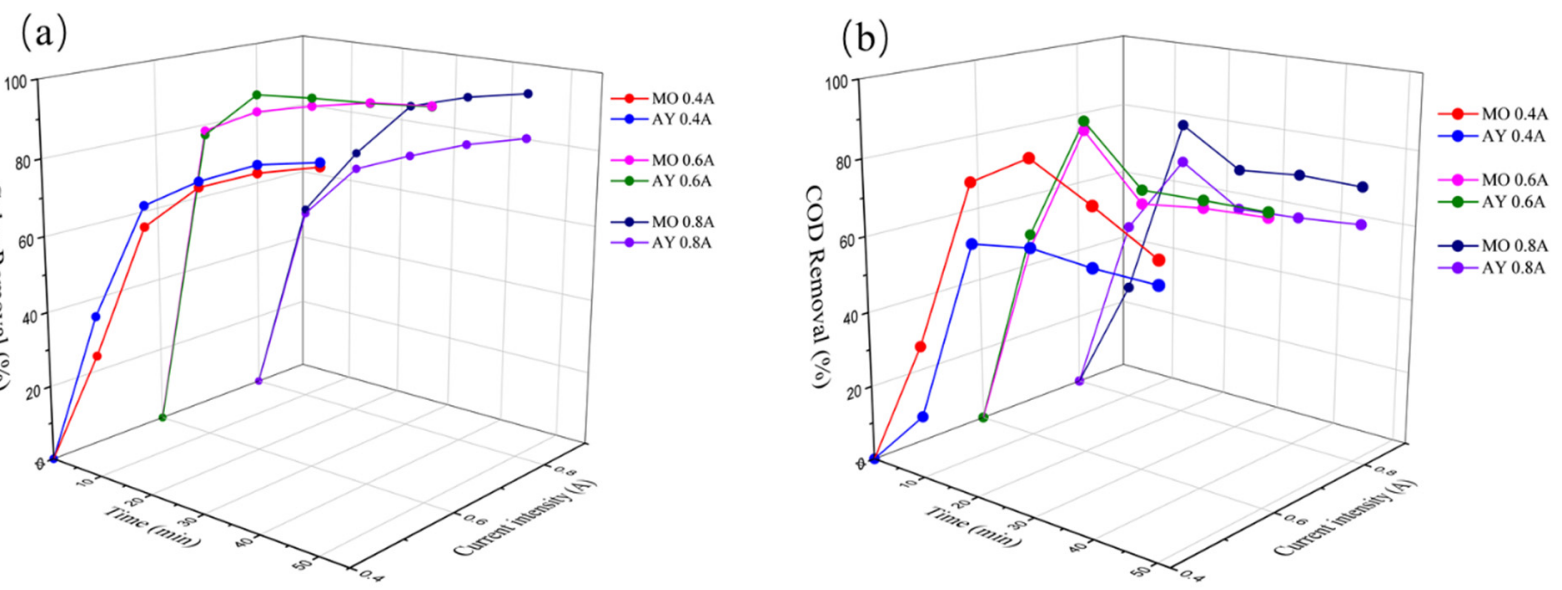

Figure 1. The effect on color and COD removal of MO (a) and AY (b) in wastewater with different current intensity.

As shown in Figure 1b, when the current intensity was set at $0.6 \mathrm{~A}$, the optimum COD removal rates for $\mathrm{MO}$ and $\mathrm{AY}$ could reach $86.2 \%$ and $88.6 \%$ at $20 \mathrm{~min}$ individually. The COD removal rates increased with the current intensity within the first $20 \mathrm{~min}$ due to the complete adsorption of contamination onto the flocs. However, the COD removal rates appearing to display a decreasing trend subsequently remained relatively stable over time. On one side, dissolved ferrous iron could be oxidized by the COD agent in the PREC process [38]. On the other side, active free radicals, such as $\cdot \mathrm{OH}$ and $\mathrm{O}_{2} \cdot{ }^{-}$, could be generated by catalyzing $\mathrm{O}_{2}$ and $\mathrm{Fe}^{2+}$ during the PREC process [39], thus oxidative degradation occurred during the subsequent reaction process, generating hardly degradable by-products containing a benzene ring structure. Therefore, the COD removal could be achieved quickly in the initial stage, while further oxidative degradation needed to be enhanced after then.

\subsection{The Influence of $p H$}

The $\mathrm{pH}$ of the aqueous solution is regarded as another factor for removing contaminants effectively during the electrocoagulation process $[40,41]$, which could influence the dissolution of electrodes, as well as the structure and morphology of hydroxide flocs generated from the dissolved anode, thus affecting the contamination removal efficiency [15]. In the PREC process, Fe was oxidized at the anode $\left(\mathrm{Fe} \rightarrow \mathrm{Fe}^{2+}+2 \mathrm{e}^{-}, \mathrm{Fe}^{2+} \rightarrow \mathrm{Fe}^{3+}+\mathrm{e}^{-}, \mathrm{Fe} \rightarrow \mathrm{Fe}^{3+}+3 \mathrm{e}^{-}\right)$, while reduction reaction was produced at the cathode $\left(2 \mathrm{H}_{2} \mathrm{O}+2 \mathrm{e}^{-} \rightarrow 2 \mathrm{OH}^{-}+\mathrm{H}_{2}\right)$. Therefore, iron hydroxide complexes were formed in the solution, and the surface charge of the electrocoagulation flocs also varied with the growth of $\mathrm{pH}$ during electrolysis. In the present study, the influences of $\mathrm{pH}$ values with 3.0,6.0, and 9.0 on the removal efficiencies of $\mathrm{MO}$ and $\mathrm{AY}$ in the simulated wastewater were estimated separately, with the conditions of $2 \mathrm{~g} \mathrm{~L}^{-1}$ $\mathrm{NaCl}$ and current intensity at $0.6 \mathrm{~A}$. As shown in Figure 2a, the color removal efficiencies of $\mathrm{MO}$ and $\mathrm{AY}$ increased rapidly in the initial $20 \mathrm{~min}$, and improved progressively during the next reaction process. Moreover, solutions with a neutral $\mathrm{pH}$ at 6.0 were more favorable than the acidic and alkaline solutions for the degradation of MO and AY by the PREC treatment, and the color removal efficiencies for $\mathrm{MO}$ and $\mathrm{AY}$ were up to $98.7 \%$ and $98.6 \%$, respectively. In the acidic environment, the iron electrode was inclined to be dissolved, with the form of $\mathrm{Fe}^{2+}$ or $\mathrm{Fe}^{3+}$ in the aqueous solution. In the alkaline environment, the sediment of $\mathrm{Fe}(\mathrm{OH})_{3}$ and $\mathrm{Fe}(\mathrm{OH})_{2}$ could develop a passivating surface layer at the electrode, because their solubility limits were exceeded [42]. Based upon the predominance-zone diagram for Fe(II) and Fe (III) species in the aqueous solution in the function of $\mathrm{pH}$ [43], in the neutral solution of $\mathrm{pH}$ at 6.0, the precipitation of $\mathrm{Fe}(\mathrm{OH})_{2}$ and $\mathrm{Fe}(\mathrm{OH})_{3}$ were gradually generated in the solution to remove $\mathrm{MO}$ and $\mathrm{AY}$ contaminants mainly by the adsorption of enmeshment. Consequently, the optimum $\mathrm{pH}$ value for the elimination of $\mathrm{MO}$ and $\mathrm{AY}$ from aqueous solutions could be fixed at 6.0. 

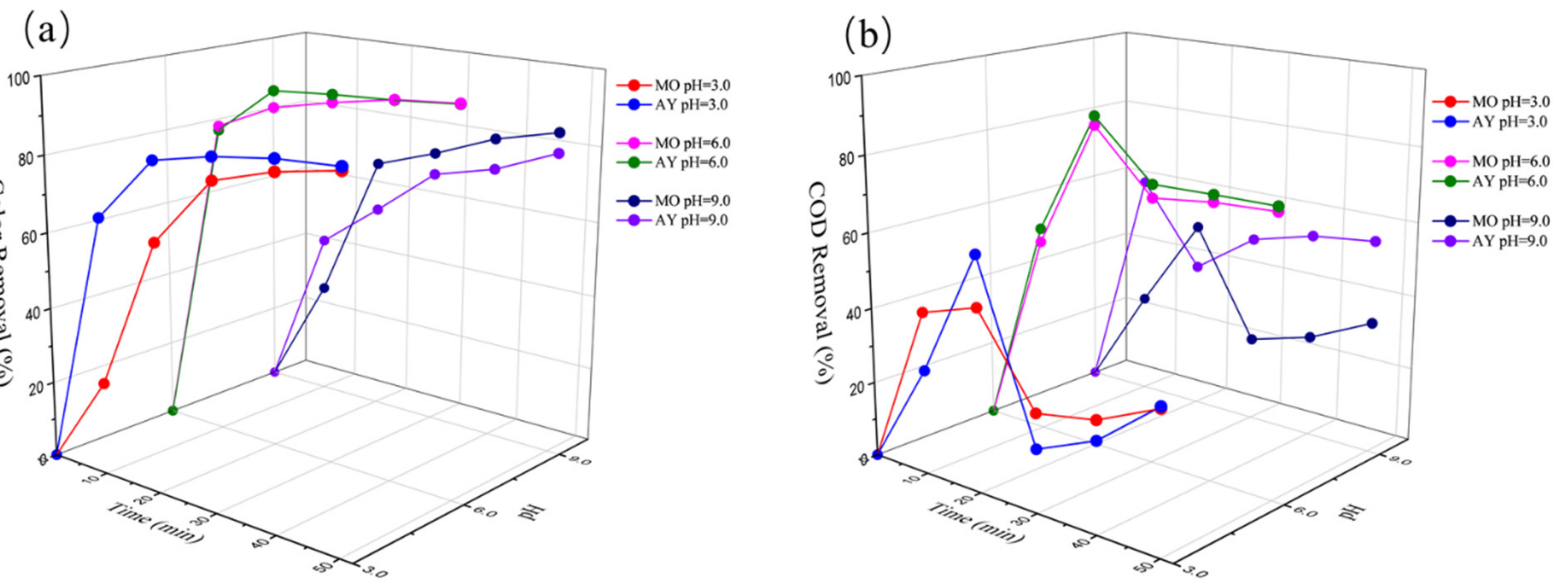

Figure 2. The effect on color and COD removal of $\mathrm{MO}(\mathbf{a})$ and $\mathrm{AY}(\mathbf{b})$ in wastewater with diverse $\mathrm{pH}$.

As shown in Figure 2b, the COD removal of MO and AY increased in the initial $20 \mathrm{~min}$, but decreased following this. This may be related to the strengthening adsorption in the initial stage, while the chemical structure was destroyed by $\cdot \mathrm{OH}$ and formed a benzene ring later [39]. In addition, when the $\mathrm{pH}$ values were 3.0, 6.0, and 9.0, the COD removal rates of $\mathrm{MO}$ at $20 \mathrm{~min}$ reached $48.0 \%, 86.2 \%$, and $51.2 \%$, respectively. Meanwhile, the COD removal rates of AY achieved $61.3 \%, 88.6 \%$, and $39.8 \%$, respectively. Therefore, the $\mathrm{pH}$ value of 6.0 was suitable for the elimination of $\mathrm{MO}$ and $\mathrm{AY}$ from aqueous solutions.

\subsection{The Influence of Electrolyte}

In the PREC process, the suitable supporting electrolyte in solution could avoid passivation of electrodes, increase the solution conductivity, accelerate the rate of proton migration, and diminish the ohmic drop and the energy consumption [44]. In the present study, the effects of three electrolytes $\left(\mathrm{Na}_{2} \mathrm{SO}_{4}, \mathrm{Na}_{2} \mathrm{CO}_{3}\right.$, and $\left.\mathrm{NaCl}\right)$ on the degradation of $\mathrm{MO}$ and $\mathrm{AY}$ by the PREC were investigated, with the current intensity at $0.6 \mathrm{~A}$ and $\mathrm{pH}$ at 6.0. As shown in Figure 3a,b, when the electrolyte was $\mathrm{Na}_{2} \mathrm{SO}_{4}$ or $\mathrm{Na}_{2} \mathrm{CO}_{3}$, the color and $\mathrm{COD}$ removal for either $\mathrm{MO}$ or $\mathrm{AY}$ were less effective. When the electrolyte was $\mathrm{Na}_{2} \mathrm{SO}_{4}$, $\mathrm{Na}_{2} \mathrm{CO}_{3}$ and $\mathrm{NaCl}$, the color removal rates of $\mathrm{MO}$ at 20 min were $54.9 \%, 74.8 \%$, and $90.7 \%$, meanwhile, $75.3 \%, 60.4 \%$, and $95.3 \%$ for AY, respectively. Correspondingly, the COD removal rates of $\mathrm{MO}$ at $20 \mathrm{~min}$ were $34.5 \%, 65.3 \%$, and $86.2 \%$, but $70.0 \%, 49.0 \%$, and $88.6 \%$ for AY, respectively. Therefore, the electrolyte of $\mathrm{NaCl}$ was beneficial for the degradation of azo dyes, contributing to improved electrical conductivity of the solution using $\mathrm{NaCl}$, thus increasing the overall removal efficiency. In addition, $\mathrm{Cl}^{-}$could generate $\mathrm{Cl}_{2}$ during the procedure of chlorine evolution reaction, and then hydrolysis reaction happened in the electrocoagulation system for the generation of $\mathrm{HClO}$, which simultaneously strengthened the attack effect of the base groups in $\mathrm{MO}$ and $\mathrm{AY}$ and the oxidation of oxides [44]. On the other hand, the chloride medium significantly favored the PREC process, owing to large corrosive power of chlorides that could promote the release of coagulant species. In addition, the color and $\mathrm{COD}$ removal efficiency of $\mathrm{AY}$ were superior to the $\mathrm{MO}$ without the influence of electrolytes, which demonstrates that the chemical structure of AY is inclined to be treated by the PREC technique. Based upon the functional group of electron-donating group involving - $\mathrm{OH}$ of AY might easily result in electric attraction with Fe hydroxide flocs, or redox reaction in the solution [30]. This phenomenon requires further analysis in regard to the influence of functional groups. Therefore, $\mathrm{NaCl}$ can be considered as the optimal electrolyte applied in the PREC treatment of MO and AY in simulated wastewater. 

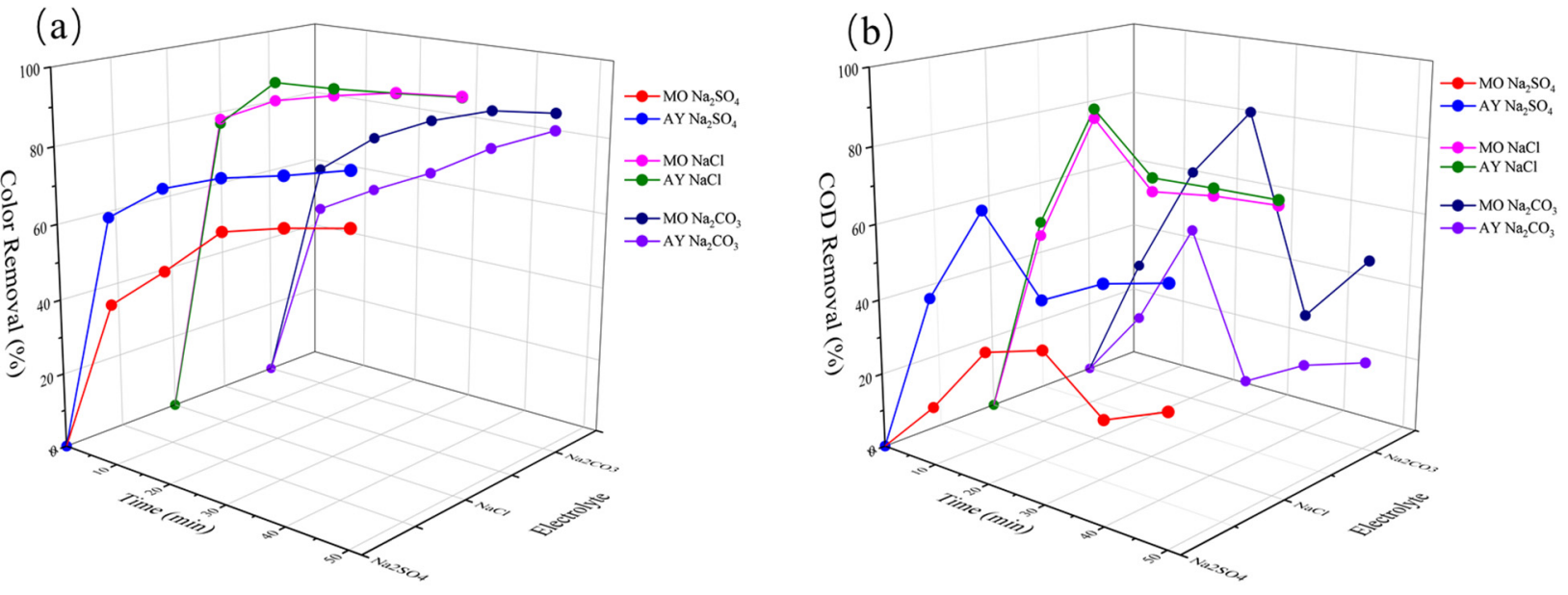

Figure 3. The effect on color and COD removal of MO (a) and AY (b) in wastewater with various electrolytes.

\subsection{Analysis of RSM}

RSM is an improved method that optimizes the process and operating variables at different levels [45]. In the present study, three significant influencing parameters are selected and optimized at three levels through ANOVA, mathematical modeling, and the color removal rates of $\mathrm{MO}$ and $\mathrm{AY}$ in the PREC process are the response value. The test results are listed in Table 2.

Table 2. Results of the experiment of MO and AY.

\begin{tabular}{|c|c|c|c|c|c|c|c|c|}
\hline \multirow[b]{2}{*}{$\begin{array}{c}\text { The Experiment } \\
\text { Number }\end{array}$} & \multicolumn{4}{|c|}{ MO } & \multicolumn{4}{|c|}{ AY } \\
\hline & $\begin{array}{c}\text { Current } \\
\text { Intensity (A) }\end{array}$ & $\begin{array}{l}\text { Time } \\
\text { (min) }\end{array}$ & $\mathrm{pH}$ & $\begin{array}{c}\text { Color } \\
\text { Removal Rate }\end{array}$ & $\begin{array}{c}\text { Current } \\
\text { Intensity (A) }\end{array}$ & $\begin{array}{l}\text { Time } \\
\text { (min) }\end{array}$ & $\mathrm{pH}$ & $\begin{array}{c}\text { Color } \\
\text { Removal Rate }\end{array}$ \\
\hline 1 & 0.60 & 10.00 & 3.00 & 24.8 & 0.80 & 30.00 & 3.00 & 99.08 \\
\hline 2 & 0.40 & 10.00 & 6.00 & 65.7 & 0.40 & 30.00 & 3.00 & 99.01 \\
\hline 3 & 0.40 & 30.00 & 3.00 & 98.33 & 0.40 & 10.00 & 6.00 & 75.6 \\
\hline 4 & 0.60 & 50.00 & 9.00 & 85.4 & 0.60 & 10.00 & 3.00 & 67.1 \\
\hline 5 & 0.80 & 30.00 & 3.00 & 90.77 & 0.60 & 10.00 & 9.00 & 69 \\
\hline 6 & 0.60 & 30.00 & 6.00 & 94.3 & 0.80 & 50.00 & 6.00 & 85 \\
\hline 7 & 0.80 & 50.00 & 6.00 & 99.3 & 0.60 & 30.00 & 6.00 & 95 \\
\hline 8 & 0.80 & 30.00 & 9.00 & 97.95 & 0.60 & 50.00 & 3.00 & 91.2 \\
\hline 9 & 0.80 & 10.00 & 6.00 & 74.1 & 0.80 & 30.00 & 9.00 & 97.31 \\
\hline 10 & 0.60 & 50.00 & 3.00 & 90.2 & 0.60 & 30.00 & 6.00 & 98.83 \\
\hline 11 & 0.40 & 50.00 & 6.00 & 91 & 0.80 & 10.00 & 6.00 & 54 \\
\hline 12 & 0.60 & 10.00 & 9.00 & 29.9 & 0.40 & 30.00 & 9.00 & 99.24 \\
\hline 13 & 0.60 & 30.00 & 6.00 & 95.84 & 0.60 & 30.00 & 6.00 & 96.76 \\
\hline 14 & 0.40 & 30.00 & 9.00 & 94.22 & 0.40 & 50.00 & 6.00 & 72 \\
\hline 15 & 0.60 & 30.00 & 6.00 & 94.85 & 0.60 & 50.00 & 9.00 & 80.1 \\
\hline
\end{tabular}

The significance of the model and its items were evaluated via the F-value and p-value by ANOVA. When the p-value was lower than 0.05, the test variables were significant. As shown in Table 3, the MO independent variables of time $\left(\mathrm{B}\right.$ and $\left.\mathrm{B}^{2}\right)$ and $\mathrm{pH}\left(\mathrm{C}^{2}\right)$ were significant for the removal efficiency, however, the interaction of $A B, A C$, and $B C$ were insignificant. According to the parameters of the $p$-value $<0.05$ and $\mathrm{R}^{2}=0.9002$ obtained from the table, it concluded that the prediction model was well developed. As shown in Table 4, AY independent variables of time $\left(\mathrm{B}\right.$ and $\left.\mathrm{B}^{2}\right)$ and $\mathrm{pH}\left(\mathrm{C}^{2}\right)$ were significant, and the interaction of $\mathrm{AB}$ and $\mathrm{BC}$ was significant, while the interaction of $\mathrm{AC}$ were insignificant for the experiment. Therefore, the influence parameters for the azo dyes by the PREC followed the order of $\mathrm{B}>\mathrm{C}>\mathrm{A}$, the interaction between current intensity and time as well as the interaction between time and $\mathrm{pH}$ were impactful for $\mathrm{AY}$. The predicted $\mathrm{R}^{2}=0.8858$ was 
in reasonable agreement with the adjusted $R^{2}=0.9742$ because the difference was less than 0.2. The signal of noise ratio about Adeq Precision $=24.309>4$, indicating that the signal was adequate due to being in the desirable region. According to the parameters of $p$-value $<0.0001$ and $R^{2}=0.9908$, which concluded that the prediction model was well suitable for describing the PREC experimental data. In addition, as presented in Figure 4, all residuals spread along the straight line and exhibited the normal distribution of the obtained $\mathrm{MO}$ and $\mathrm{AY}$ removal rates. Furthermore, Figure 5 correspondingly showed the predicted values and actual values of removal rates as another confirmation.

Table 3. MO ANOVA results for response surface of quadratic model.

\begin{tabular}{|c|c|c|c|c|c|c|}
\hline Source & $\begin{array}{l}\text { Sum of } \\
\text { Squares }\end{array}$ & df & Mean Square & F-Value & $p$-Value & \\
\hline $\begin{array}{c}\text { Model } \\
\text { A-Current } \\
\text { intensity (A) } \\
\text { B-Time (min) } \\
\text { C-pH } \\
\text { AB } \\
\text { AC } \\
\text { BC } \\
\text { A`2 }^{\wedge} 2 \\
\text { B`2 } \\
\text { C`2 }^{\wedge} \\
\text { Residual } \\
\text { Lack of Fit } \\
\text { Pure Error } \\
\text { Cor Total }\end{array}$ & $\begin{array}{c}6941.66 \\
539.89 \\
3672.24 \\
20.42 \\
2.500 \mathrm{E}-003 \\
0.88 \\
24.50 \\
134.22 \\
1263.81 \\
1321.84 \\
769.85 \\
768.64 \\
1.22 \\
7711.52\end{array}$ & $\begin{array}{c}9 \\
1 \\
1 \\
1 \\
1 \\
1 \\
1 \\
1 \\
1 \\
1 \\
5 \\
3 \\
2 \\
14\end{array}$ & $\begin{array}{c}771.30 \\
539.89 \\
3672.24 \\
20.42 \\
2.500 \mathrm{E}-003 \\
0.88 \\
24.50 \\
134.22 \\
1263.81 \\
1321.84 \\
153.97 \\
256.21 \\
0.61\end{array}$ & $\begin{array}{c}5.01 \\
3.51 \\
23.85 \\
0.13 \\
1.624 \mathrm{E}-005 \\
5.739 \mathrm{E}-003 \\
0.16 \\
0.87 \\
8.21 \\
8.58\end{array}$ & $\begin{array}{l}0.0454 \\
0.1200 \\
0.0045 \\
0.7306 \\
0.9969 \\
0.9426 \\
0.7064 \\
0.3933 \\
0.0352 \\
0.0326\end{array}$ & significant \\
\hline
\end{tabular}

$R^{2}=0.9002$ Adjusted $R^{2}=0.7205$ Predicted $R^{2}=-0.5951$ Adeq Presion $=7.902$

Table 4. AY ANOVA results for response surface of quadratic model.

\begin{tabular}{|c|c|c|c|c|c|c|}
\hline Source & $\begin{array}{l}\text { Sum of } \\
\text { Squares }\end{array}$ & df & Mean Square & F-Value & $p$-Value & \\
\hline Model & & 9 & & & & \multirow{4}{*}{ significant } \\
\hline A-Current & 3006.47 & 9 & 334.05 & & & \\
\hline intensity (A) & 13.68 & 1 & 13.68 & 59.72 & 0.0001 & \\
\hline B-Time (min) & 489.84 & 1 & 489.84 & 2.44 & 0.1787 & \\
\hline C-pH & 14.42 & 1 & $\begin{array}{l}409.04 \\
14.42\end{array}$ & 87.57 & 0.0002 & \\
\hline $\mathrm{AB}$ & 299.29 & 1 & $\begin{array}{c}14.42 \\
299.29\end{array}$ & 2.58 & 0.1693 & \\
\hline $\mathrm{AC}$ & 1.00 & 1 & $\begin{array}{l}299.29 \\
1.00\end{array}$ & 53.51 & 0.0007 & \\
\hline $\mathrm{BC}$ & 42.25 & 1 & & 0.18 & 0.6900 & \\
\hline $\mathrm{A}^{\wedge} 2$ & 10.69 & 1 & 42.25 & 7.55 & 0.0404 & \\
\hline $\mathrm{B} \wedge 2$ & 2041.10 & 1 & 10.69 & 1.91 & 0.2254 & \\
\hline$C^{\wedge} 2$ & 45.19 & 1 & 2041.10 & 364.89 & $<0.0001$ & \\
\hline Residual & 27.97 & 5 & 45.19 & 8.08 & 0.0362 & \\
\hline & 20.62 & 3 & 5.59 & & & \\
\hline $\begin{array}{l}\text { Lack of Fit } \\
\text { Pure Error }\end{array}$ & 7.35 & 2 & 6.87 & 1.87 & 0.3671 & Not significant \\
\hline & 3034.43 & 14 & 3.68 & & & \\
\hline
\end{tabular}

$R^{2}=0.9908$ Adjusted $R^{2}=0.9742$ Predicted $R^{2}=0.8858$ Adeq Presion $=24.309$. 

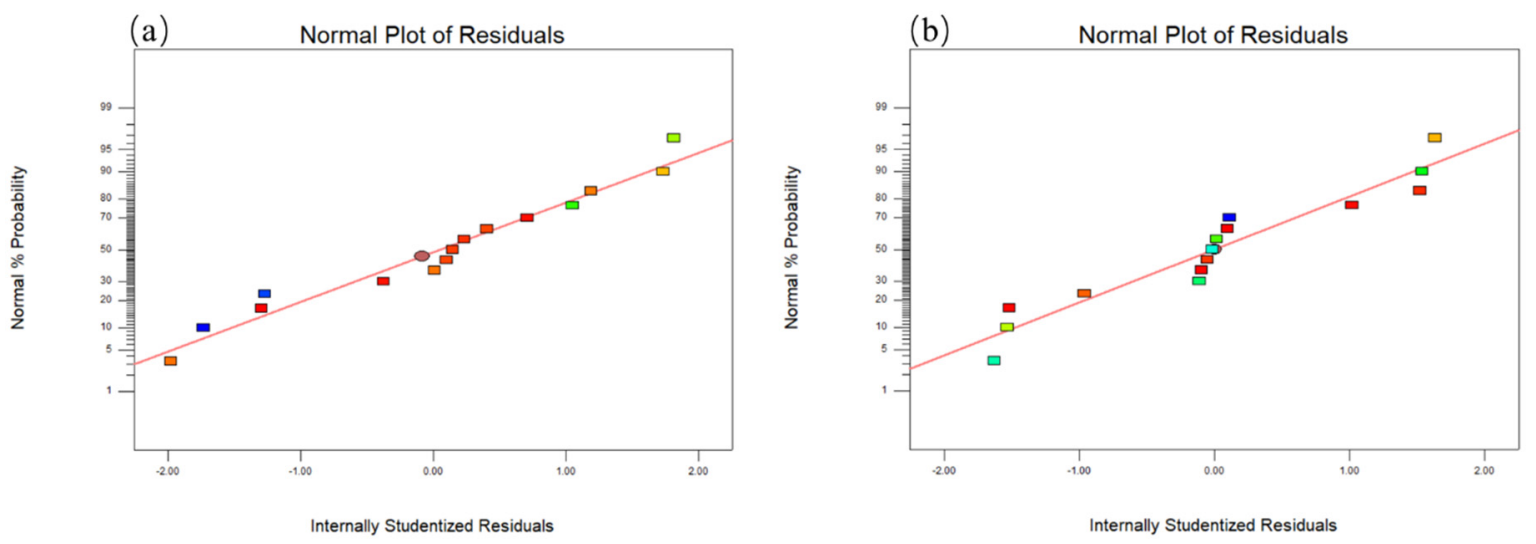

Figure 4. The Normal probability plot of studentized residuals of $\mathrm{MO}(\mathbf{a})$ and $\mathrm{AY}(\mathbf{b})$ of the model for the removal rates.
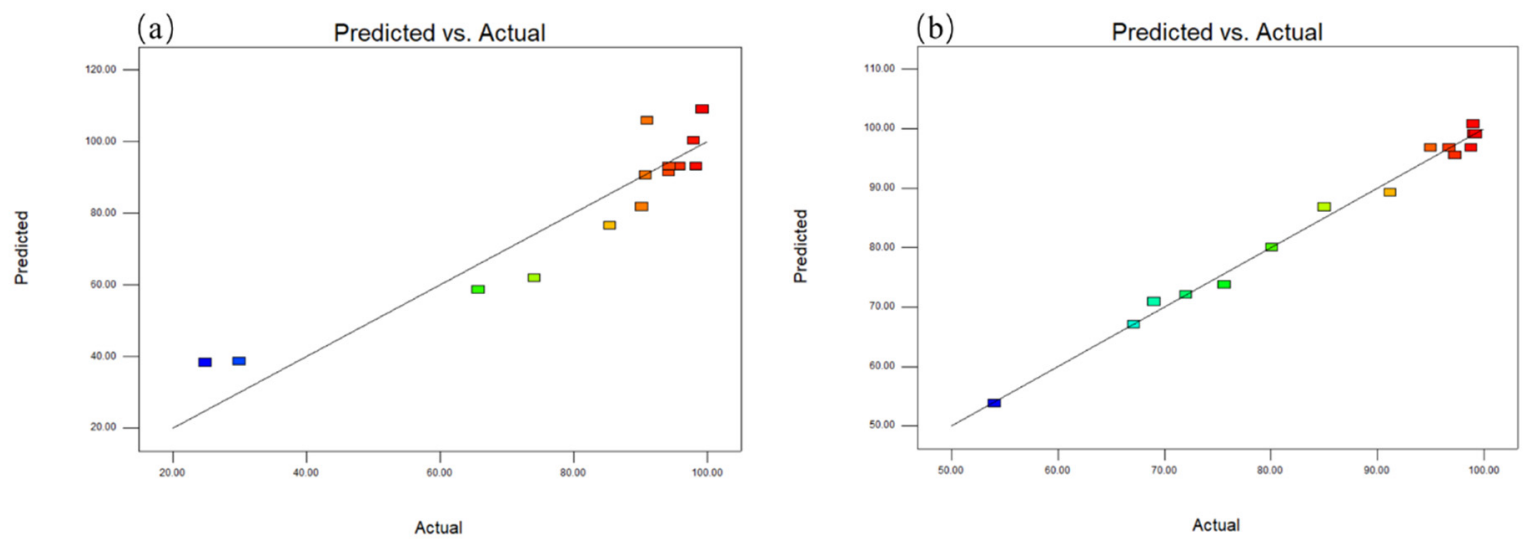

Figure 5. Experimental response values versus predicted response value of MO (a) and AY (b).

The RSM for the color removal rates according to the above three important parameters attained from the PREC experiments were depicted in Figure 6. Two parameters were demonstrated in 3D surface plots, while the other variable was kept at an optimum level $(\alpha=0)$. The interactions among the current intensity, time, and $\mathrm{pH}$ were corelated to the ANOVA results for the response surface of the quadratic model. In addition, when the color removal rate of $\mathrm{MO}$ and $\mathrm{AY}$ were predicted as $100 \%$ and $97.6 \%$, correspondingly, the optimum conditions included the current intensity of $0.71 \mathrm{~A}$ and $0.57 \mathrm{~A}$, the electrolysis time of $42.43 \mathrm{~min}$ and $31.08 \mathrm{~min}$, and the $\mathrm{pH}$ values of 6.65 and 5.59. This conclusion demonstrates that the condition of PREC treatment for AY simulated wastewater was time-saving and energy conserving and, therefore, the azo dye of AY was more easily treated by the PREC technique than by MO. The regression model was a second-order response surface by the fitting analysis of multi-linear linear regression using software, as shown in the following formula (1 for MO) and (2 for AY).

$$
\begin{gathered}
Y=93.18+1.61 \mathrm{~A}+23.59 \mathrm{~B}+2.04 \mathrm{C}-0.025 \mathrm{AB}+2.82 \mathrm{AC}+1.85 \mathrm{BC}+11.24 \mathrm{~A}^{2}-20.54 \mathrm{~B}^{2}-10.47 \mathrm{C}^{2} \\
\mathrm{Y}=96.86-1.31 \mathrm{~A}+7.82 \mathrm{~B}-1.34 \mathrm{C}+8.65 \mathrm{AB}-0.50 \mathrm{AC}-3.25 \mathrm{BC}-1.70 \mathrm{~A}^{2}-23.51 \mathrm{~B}^{2}+3.5 \mathrm{C}^{2}
\end{gathered}
$$


(a)

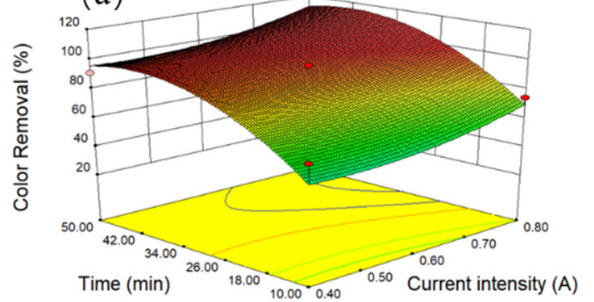

(d)

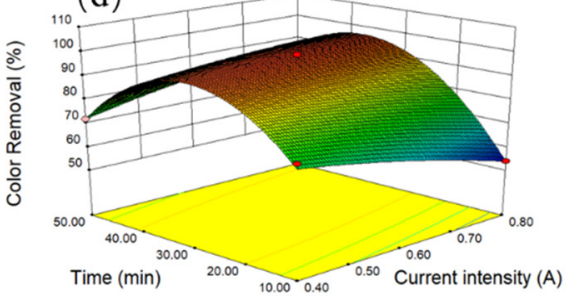

(b)

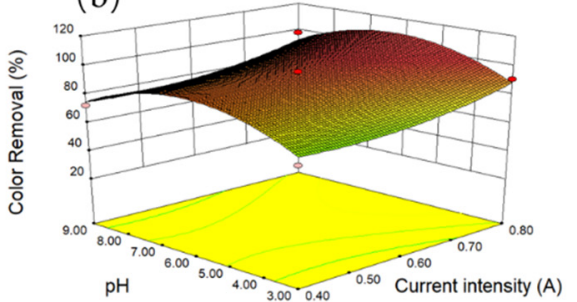

(e)

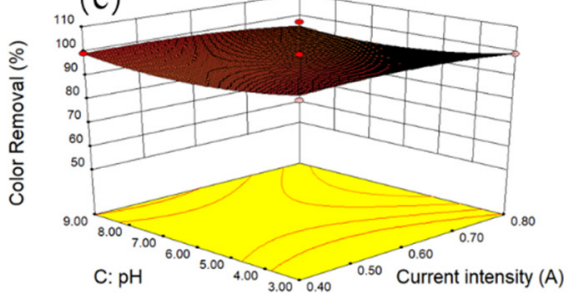

(c)

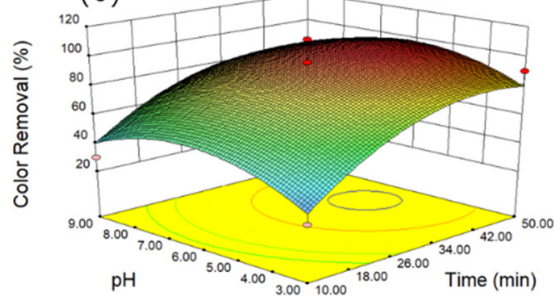

(f)

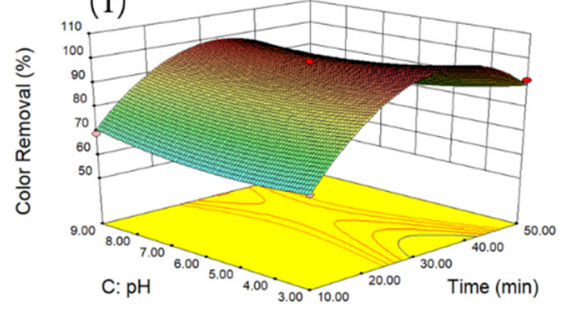

Figure 6. RSM for color removal rate of $\mathrm{MO}$ and $\mathrm{AY}$ as a function of current intensity and time (a,d), current density and $\mathrm{pH}(\mathbf{b}, \mathbf{e}), \mathrm{pH}$ and time $(\mathbf{c}, \mathbf{f})$, respectively.

\subsection{The Influence of Functional Groups}

The degradation mechanism of $\mathrm{MO}$ and $\mathrm{AY}$ throughout the procedure of PREC process were also observed continually by the UV-Vis spectrophotometry analysis, when the optimum experimental conditions of the current intensity was $0.6 \mathrm{~A}$, electrolyte was $2 \mathrm{~g} \mathrm{~L}^{-1}$ of $\mathrm{NaCl}$, and the initial $\mathrm{pH}$ value was 6.0. The recorded $\mathrm{UV}$ spectra of $\mathrm{MO}$ and $\mathrm{AY}$ in the simulated aqueous solutions before and after the PREC treatment are illustrated in Figure 7. Overall, the $\mathrm{MO}$ and $\mathrm{AY}$ spectra in the visible region and the organics degradation in the UV region between 200 and $900 \mathrm{~nm}$ were investigated. The UV-Vis absorption spectrum of the initial MO solution ( $0 \mathrm{~min}$ ) mainly covered two peaks at $248 \mathrm{~nm}$ and $462 \mathrm{~nm}$, respectively. The peak at $462 \mathrm{~nm}$ could be ascribed to the $\pi-\pi$ conjugated chain of the $-\mathrm{N}=\mathrm{N}-$, benzene ring structure, and the other one at $248 \mathrm{~nm}$ was the characteristic absorption band of the benzene ring [46]. On the other hand, the UV-Vis absorption spectrum of the original AY solution $(0 \mathrm{~min})$ contained two peaks at low wavelength of $240 \mathrm{~nm}$ and $376 \mathrm{~nm}$, due to greater unsaturation than $\mathrm{MO}$. The peak at $376 \mathrm{~nm}$ could be ascribed to the powerful $\pi-\pi$ conjugated chain of the $-\mathrm{N}=\mathrm{N}-$, benzene ring structure, $-\mathrm{NO}_{2}$, and -COO-, and the other one at $248 \mathrm{~nm}$ was the characteristic absorption band of the benzene ring. Clearly, different molecular structures resulted in the respective wavelength spectra of $\mathrm{MO}$ and $\mathrm{AY}$.

(a)

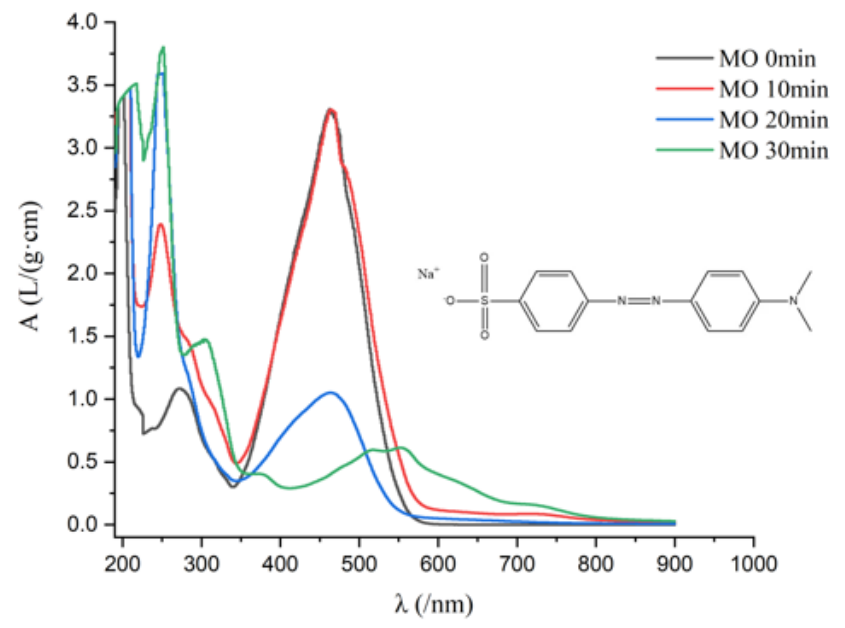

(b)

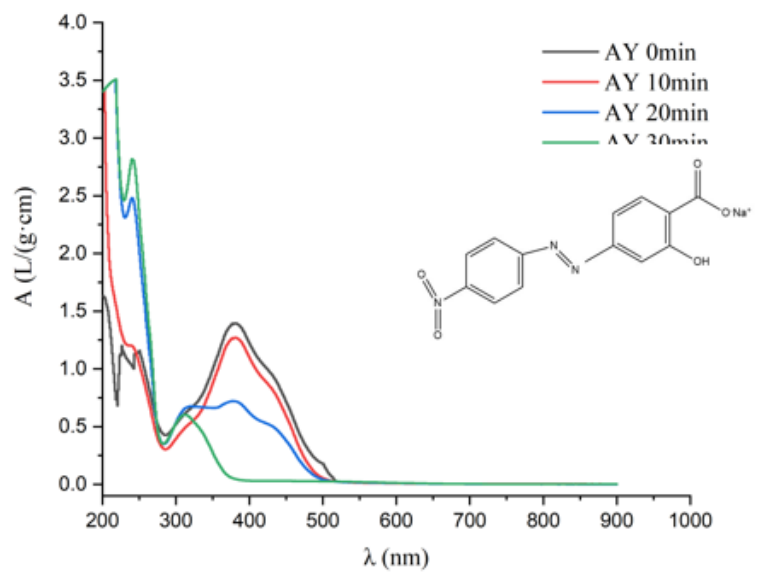

Figure 7. Absorbance spectra of $\mathrm{MO}(\mathbf{a})$ and $\mathrm{AY}(\mathbf{b})$ solution with the reaction time. 
As depicted in Figure 7a, the wavelength at $463 \mathrm{~nm}$ of $\mathrm{MO}$ was diminished with the increase of the reaction time, due to the decrease in $\mathrm{MO}$ concentration that originated from flocculation. However, the respective wavelength at $248 \mathrm{~nm}$ of the benzene ring monomer was amplified gradually; this phenomenon demonstrated that the strong $\pi-\pi$ conjugated system between the $-\mathrm{N}=\mathrm{N}$ - bond that might be destroyed due to the oxidation reaction by $\cdot \mathrm{OH}$ and $\mathrm{O}_{2} \cdot{ }^{-}$in the PREC process. Within the initial $10 \mathrm{~min}$, the absorbance at $463 \mathrm{~nm}$ was relative steady, while the COD removal rate still increased. This was likely because the adsorption on flocs was the main mechanism in the initial $10 \mathrm{~min}$, with the oxidation-reduction then potentially taking effect in the subsequent process. As shown in the Figure $7 \mathrm{~b}$, the wavelength at $376 \mathrm{~nm}$ decreased gradually with the duration time, while the wavelength at $240 \mathrm{~nm}$ increased correspondingly and red shift slowly. It as well indicated that the $-\mathrm{N}=\mathrm{N}$ - bond might be destroyed, and the new monomeric compound might be generated involving $\mathrm{p}$-phenylenediamine and aminosalicylic acid. Moreover, the absorbance at $376 \mathrm{~nm}$ and COD was altogether weakened in the initial $10 \mathrm{~min}$, which inferred that the adsorption on flocs and oxidation-reduction might come into effect simultaneously. This illustrates that the AY was propitious to promote the oxidation-reduction in the solution. Compared the functional group with $\mathrm{MO}$, the strong electron-donating group of $-\mathrm{OH}$ in $\mathrm{AY}$ might be the reason for facilitating the reaction. Possibly this is because hydroxyl groups in AY would donate electrons to iron ions, or electrolyze out additional strong oxidizable substances such as hydroxyl free radicals, enhancing the degradation efficacy for such azo dyes [47]. The trend mentioned above was also consistent with the removal rates of COD for both $\mathrm{MO}$ and $\mathrm{AY}$ increasing within the first $20 \mathrm{~min}$ and then decreasing.

\section{Conclusions}

In summary, the degradation of $\mathrm{MO}$ and $\mathrm{AY}$ with different functional groups in the simulated wastewater with Fe-Fe electrodes by the PREC technique could be feasible. Intensive studies on simulated aqueous solutions containing $\mathrm{MO}$ or $\mathrm{AY}$ were implemented on the conditions of treatment involving the current intensity, $\mathrm{pH}$, and electrolyte. The optimal removal rates for $\mathrm{MO}$ and $\mathrm{AY}$ could be achieved at $98.7 \%$ and $98.6 \%$ with Fe-Fe electrodes, when the current intensity and $\mathrm{pH}$ were set to $0.6 \mathrm{~A}$ and 6.0, respectively, and the electrolyte was selected as $\mathrm{NaCl}$. An accurate predicted method of RSM was established to optimize the PREC process for the removal of $\mathrm{MO}$ and AY from simulated wastewater involving the above three influencing parameters. The reaction time was the main influence for both azo dyes, while the condition of PREC treatment for AY simulated wastewater was time-saving and energy conserving. Furthermore, comparing the temporal absorption variation in the absorbances of $\mathrm{MO}$ and $\mathrm{AY}$ throughout the procedure of PREC, the $-\mathrm{N}=\mathrm{N}$ bond was the breakout and the functional group of $-\mathrm{OH}$ in $\mathrm{AY}$ might play a vital role in the improvement of removal efficiency. As a result, the present study revealed that the excellent and efficient removal for color and COD, as well as the degradation of azo dyes could be achieved by the PREC. The RSM was a powerful tool for optimizing the operational parameters. The PREC technique could be a potential method to eliminate the contaminations of azo dyes with diverse functional groups from various wastewaters. In addition, extensive investigations about diverse electrolytes actuating on the electrode for the RSM analysis need to be implemented in our future studies.

Author Contributions: Conceptualization, Y.L. and J.B.; Data curation, C.L. and Y.L.; Formal analysis, C.L., W.Y. and L.S.; Funding acquisition, J.B.; Investigation, C.L. and X.W.; Methodology, Y.L. and J.B.; Project administration, Y.L. and J.B.; Resources, Y.L. and J.B.; Software, C.L. and L.S.; Supervision, Y.L., J.B. and X.W.; Validation, W.Y.; Visualization, L.S.; Writing-original draft, C.L. and Y.L.; Writing-review \& editing, Y.L. and J.B. All authors have read and agreed to the published version of the manuscript. 
Funding: This research was funded by the National Natural Science Foundation of China (No.21976124 and No.21507092), the Natural Science Foundation of Liaoning Province of China (No.2019-ZD-0217), and Liaoning Revitalization Talents Program (No.XLYC2007195).

Acknowledgments: Thanks for the financial supports from the National Natural Science Foundation of China (No.21976124 and No.21507092), the Natural Science Foundation of Liaoning Province of China (No.2019-ZD-0217), and Liaoning Revitalization Talents Program (No. XLYC2007195).

Conflicts of Interest: The authors declare no conflict of interest.

\section{References}

1. Pattnaik, P.; Dangayach, G.; Bhardwaj, A.K. A review on the sustainability of textile industries wastewater with and without treatment methodologies. Rev. Environ. Health 2018, 33, 163-203. [CrossRef] [PubMed]

2. Solis, M.; Solis, A.; Perez, H.I.; Manjarrez, N. Flores M Microbial decolouration of azo dyes: A review. Process. Biochem. 2012, 47, 1723-1748. [CrossRef]

3. Saratale, R.G.; Gandhi, S.S.; Purankar, M.V.; Kurade, M.; Govindwar, S.; Oh, S.E.; Saratale, G.D. Decolorization and detoxification of sulfonated azo dye C.I. Remazol Red and textile effluent by isolated Lysinibacillus sp. RGS. J. Biosci. Bioeng. 2013, 115, 658-667. [CrossRef]

4. Puvaneswari, N.; Muthukrishnan, J.; Gunasekaran, P. Toxicity assessment and microbial degradation of azo dyes. Indian J. Exp. Boil. 2006, 44, 618-626.

5. Ozturk, E.; Cinperi, N.C. Water efficiency and wastewater reduction in an integrated woolen textile mill. J. Clean. Prod. 2018, 201, 686-696. [CrossRef]

6. Hassan, M.M.; Carr, C.M. A critical review on recent advancements of the removal of reactive dyes from dyehouse effluent by ion-exchange adsorbents. Chemosphere 2018, 209, 201-219. [CrossRef]

7. Abe, F.R.; Soares, A.M.; de Oliveira, D.P.; Gravato, C.A. Toxicity of dyes to zebrafish at the biochemical level: Cellular energy allocation and neurotoxicity. Environ. Pollut. 2018, 235, 255-262. [CrossRef]

8. Du, C.F.; Xue, Y.T.; Wu, Z.S.; Wu, Z.L. Microwave-assisted one-step preparation of macadamia nut shell-based activated carbon for efficient adsorption of Reactive Blue. New. J. Chem. 2017, 41, 15373-15383. [CrossRef]

9. Kumar, P.S.; Sivaranjanee, R.; Vinothini, U.; Raghavi, M.; Rajasekar, K.; Ramakrishnan, K. Adsorption of dye onto raw and surface modified tamarind seeds: Isotherms, process design, kinetics and mechanism. DESALINATION Water Treat. 2014, 52, 2620-2633. [CrossRef]

10. Chung, K.-T. Azo dyes and human health: A review. J. Environ. Sci. Health Part C 2016, 34, 233-261. [CrossRef]

11. Saleh, T.; Gupta, V.K. Photo-catalyzed degradation of hazardous dye methyl orange by use of a composite catalyst consisting of multi-walled carbon nanotubes and titanium dioxide. J. Colloid Interface Sci. 2012, 371, 101-106. [CrossRef]

12. Chankhanittha, T.; Somaudon, V.; Watcharakitti, J.; Piyavarakorn, V.; Nanan, S. Performance of solvothermally grown Bi2MoO6 photocatalyst toward degradation of organic azo dyes and fluoroquinolone antibiotics. Mater. Lett. 2020, 258, 126764. [CrossRef]

13. Punzi, M.; Nilsson, F.; Anbalagan, A.; Svensson, B.-M.; Jönsson, K.; Mattiasson, B.; Jonstrup, M. Combined anaerobic-ozonation process for treatment of textile wastewater: Removal of acute toxicity and mutagenicity. J. Hazard. Mater. 2015, 292, 52-60. [CrossRef] [PubMed]

14. Subramaniam, R.; Ponnusamy, S.K. Novel adsorbent from agricultural waste (cashew NUT shell) for methylene blue dye removal: Optimization by response surface methodology. Water Resour. Ind. 2015, 11, 64-70. [CrossRef]

15. Bao, Y.; Niu, J.; Xu, Z.; Gao, D.; Shi, J.; Sun, X.; Huang, Q. Removal of perfluorooctane sulfonate (PFOS) and perfluorooctanoate (PFOA) from water by coagulation: Mechanisms and influencing factors. J. Colloid Interface Sci. 2014, 434, 59-64. [CrossRef] [PubMed]

16. Niu, J.; Li, Y.; Shang, E.; Xu, Z.; Liu, J. Electrochemical oxidation of perfluorinated compounds in water. Chemosphere 2016, 146, 526-538. [CrossRef]

17. Prajapati, A.K.; Chaudhari, P.K. Electrochemical treatment of rice grain-based distillery effluent: Chemical oxygen demand and colour removal. Environ. Technol. 2013, 35, 242-249. [CrossRef] [PubMed]

18. Stergiopoulos, D.; Dermentzis, K.; Giannakoudakis, P.; Sotiropoulos, S. Electrochemical decolorization and removal of indigo carmine textile dye from wastewater. Glob. Nest. J. 2014, 16, 499-506.

19. Cui, D.; Cui, M.-H.; Liang, B.; Liu, W.-Z.; Tang, Z.-E.; Wang, A.-J. Mutual effect between electrochemically active bacteria (EAB) and azo dye in bio-electrochemical system (BES). Chemosphere 2020, 239, 124787. [CrossRef]

20. Yavuz, Y.; Ögütveren, Ü.B. Treatment of industrial estate wastewater by the application of electrocoagulation process using iron electrodes. J. Environ. Manag. 2018, 207, 151-158. [CrossRef]

21. Shi, H.; Chiang, S.-Y.; Wang, Y.; Wang, Y.; Liang, S.; Zhou, J.; Fontanez, R.; Gao, S.; Huang, Q. An electrocoagulation and electrooxidation treatment train to remove and degrade per- and polyfluoroalkyl substances in aqueous solution. Sci. Total. Environ. 2021, 788, 147723. [CrossRef] [PubMed]

22. Khalifah, A.; Hayfaa, A.M.; Joseph, A.A.; Laith, A.A.; Rafid, A.K.; Mawada, A.; Abuduljaleel, A.J. Electrochemical removal of brilliant green dye from wastewater. In IOP Conference Series: Materials Science and Engineering; IOP Publishing: Bristol, UK, 2020; Volume 888, p. 012036. 
23. Abdulhadi, B.A.; Kot, P.; Hashim, K.S.; Shaw, A.; Al Khaddar, R. Influence of current density and electrodes spacing on reactive red 120 dye removal from dyed water using electrocoagulation/electroflotation (EC/EF) process. In IOP Conference Series: Materials Science and Engineering; IOP Publishing: Bristol, UK, 2019; Volume 584, p. 012035. [CrossRef]

24. Núñez, J.; Yeber, M.; Cisternas, N.; Thibaut, R.; Medina, P.; Carrasco, C. Application of electrocoagulation for the efficient pollutants removal to reuse the treated wastewater in the dyeing process of the textile industry. J. Hazard. Mater. 2019, 371, 705-711. [CrossRef]

25. Bao, J.; Yu, W.-J.; Liu, Y.; Wang, X.; Liu, Z.-Q.; Duan, Y.-F. Removal of perfluoroalkanesulfonic acids (PFSAs) from synthetic and natural groundwater by electrocoagulation. Chemosphere 2020, 248, 125951. [CrossRef]

26. Liu, Y.; Hu, X.-M.; Zhao, Y.; Wang, J.; Lu, M.-X.; Peng, F.-H.; Bao, J. Removal of perfluorooctanoic acid in simulated and natural waters with different electrode materials by electrocoagulation. Chemosphere 2018, 201, 303-309. [CrossRef]

27. Pi, K.W.; Xiao, Q.; Zhang, H.Q.; Xia, M.; Gerson, A.R. Decolorization of synthetic Methyl Orange wastewater by electrocoagulation with periodic reversal of electrodes and optimization by RSM. Process. Saf. Environ. Prot. 2014, 92, 796-806. [CrossRef]

28. Oliveira, M.T.; Garcia, L.F.; Siqueira, A.C.R.; Somerset, V.; Gil, E.S. Electrocoagulation of the indigo carmine dye using electrodes produced from the compression of metallurgical filing wastes. Int. J. Environ Sci. Technol. 2019, 17, 1657-1662. [CrossRef]

29. Gautam, K.; Kamsonlian, S.; Kumar, S. Removal of Reactive Red 120 dye from wastewater using electrocoagulation: Optimization using multivariate approach, economic analysis, and sludge characterization. Sep. Sci. Technol. 2019, 55, 3412-3426. [CrossRef]

30. Hashim, K.S.; Shaw, A.; Al Khaddar, R.; Pedrola, M.O.; Phipps, D. Iron removal, energy consumption and operating cost of electrocoagulation of drinking water using a new flow column reactor. J. Environ. Manag. 2017, 189, 98-108. [CrossRef]

31. Karamati-Niaragh, E.; Moghaddam, M.R.A.; Emamjomeh, M.M.; Nazlabadi, E. Evaluation of direct and alternating current on nitrate removal using a continuous electrocoagulation process: Economical and environmental approaches through RSM. $J$. Environ. Manag. 2019, 230, 245-254. [CrossRef]

32. Abbasi, S.; Mirghorayshi, M.; Zinadini, S.; Zinatizadeh, A. A novel single continuous electrocoagulation process for treatment of licorice processing wastewater: Optimization of operating factors using RSM. Process Saf. Environ. Prot. 2020, 134, 323-332. [CrossRef]

33. Bhatti, M.S.; Kapoor, D.; Kalia, R.K.; Reddy, A.S.; Thukral, A.K. RSM and ANN modeling for electrocoagulation of copper from simulated wastewater: Multi objective optimization using genetic algorithm approach. Desalination 2011, 274, 74-80. [CrossRef]

34. Verma, A.K. Treatment of textile wastewaters by electrocoagulation employing Fe-Al composite electrode. J. Water Process. Eng. 2017, 20, 168-172. [CrossRef]

35. Irki, S.; Ghernaout, D.; Naceur, M.W. Decolourization of Methyl Orange (MO) by electrocoagulation (EC) using iron electrodes under a magnetic field (MF). DESALINATION Water Treat. 2017, 79, 368-377. [CrossRef]

36. Tahreen, A.; Jami, M.S.; Ali, F. Role of electrocoagulation in wastewater treatment: A developmental review. J. Water Process Eng. 2020, 37, 101440. [CrossRef]

37. Brahmi, K.; Bouguerra, W.; Hamrouni, B.; Elaloui, E.; Loungou, M.; Tlili, Z. Investigation of electrocoagulation reactor design parameters effect on the removal of cadmium from synthetic and phosphate industrial wastewater. Arab. J. Chem. 2019, 12, 1848-1859.

38. Devlin, T.R.; Kowalski, M.S.; Pagaduan, E.; Zhang, X.; Wei, V.; Oleszkiewicz, J.A. Electrocoagulation of wastewater using aluminum, iron, and magnesium electrodes. J. Hazard. Mater. 2019, 368, 862-868. [CrossRef] [PubMed]

39. Qian, A.; Yuan, S.; Xie, S.; Tong, M.; Zhang, P.; Zheng, Y. Oxidizing Capacity of Iron Electrocoagulation Systems for Refractory Organic Contaminant Transformation. Environ. Sci. Technol. 2019, 53, 12629-12638. [CrossRef] [PubMed]

40. Mollah, M.Y.A.; Gomes, J.A.; Das, K.K.; Cocke, D.L. Electrochemical treatment of Orange II dye solution-Use of aluminum sacrificial electrodes and floc characterization. J. Hazard. Mater. 2010, 174, 851-858. [CrossRef] [PubMed]

41. Naje, A.S.; Chelliapan, S.; Zakaria, Z.; Ajeel, M.A.; Alaba, P.A. A review of electrocoagulation technology for the treatment of textile wastewater. Rev. Chem. Eng. 2017, 33, 263-292. [CrossRef]

42. Ingelsson, M.; Yasri, N.; Roberts, E.P. Electrode passivation, faradaic efficiency, and performance enhancement strategies in electrocoagulation-a review. Water Res. 2020, 187, 116433. [CrossRef]

43. Garcia-Segura, S.; Eiband, M.M.S.G.; Melo, J.V.; Martínez-Huitlea, C.A. Electrocoagulation and advanced electrocoagulation processes: A general review about the fundamentals, emerging applications and its association with other technologies. $J$. Electroanal. Chem. 2017, 801, 267-299. [CrossRef]

44. Hakizimana, J.N.; Gourich, B.; Chafi, M.; Stiriba, Y.; Vial, C. Electrocoagulation process in water treatment: A review of electrocoagulation modeling approaches. Desalination 2017, 404, 1-21. [CrossRef]

45. Wu, Z.; Dong, J.; Yao, Y.; Yang, Y.; Wei, F. Continuous flowing electrocoagulation reactor for efficient removal of azo dyes: Kinetic and isotherm studies of adsorption. Environ. Technol. Innov. 2021, 22, 101448. [CrossRef]

46. Nisha, S.K.; Sivakumar, S.; Achutha, S. Polyvinyl alcohol/methyl orange flexible film as reusable pH indicator. Mater. Today Proc. 2021, 42, 1008-1011. [CrossRef]

47. Kong, X.W. Organic Chemistry, 2nd ed.; Chemical Industry Press: Beijing, China, 2020; pp. 73-74. (In Chinese) 